\title{
Twelve Communicational Principles of Propaganda
}

\author{
Ştefan Vlăduţescu \\ University of Craiova, 13 A. I. Cuza Street, 200585, Craiova, Romania \\ E-mail address: stefan.vladutescu@yahoo.com
}

\section{ABSTRACT}

This study examines how is structured the propaganda (pyramid of prop gand and an a of development of propaganda, in order to detach operating principles of vaga an Irves gative approach is meta-analytical. It assumes that propaganda is a type of sua commu cation. It examines, first, the ontological elements of communication and it is fo nd that cri ele sents are the target-group, the propagandistic message and the planning. It is a ai $\mathrm{le}$ element get-group) and two ideational and intangible elements (propagandistic message a d pla $\mathrm{v}$ ). Then, starting from the 6 propaganda techniques and rules set by Jean-Marie D ach $(190$ 2094), we identify 12 communicational principles of propaganda. The $12 \mathrm{pr}$ aciples are not re, arded as principles of existence, but as principles of efficiency of propaganda.

Keywords: persuasive communication ; pyramid of propas a prin ples of propaganda

\section{INTRODUCTION}

Propaganda is a matte o a on subtle and clear ideas it is a in of persuasion, because it is done only by persuasive methods (Rhodes, 198\%, vlor, 199 Yopaganda is the most important form of persuasion. After it come the mo pulà disinfermation and intoxication. A. R. Pratkanis, A. Pratkanis and Aronson E. (2-1) opine t. today we live in the "Age of Propaganda". As a social practice propaganda $p^{2}$ enom na emerge, from the influence of large groups, crowds, associations, partied, mas

Concept o ring sy $\mathrm{ch}$ social practice meanings was established in the Middle Age; it was r cea in the ron and was taken there by social scientists. In the twentieth century, pr gand became political and war weapon. J. D. Squires (1935), J. A. Leith (1965), HC Peter and M. Balfour (1979) analyzed the incidence idea of propaganda and propaga in France, the U.S. and the UK, the period from 1914 to 1917. P. Kenez (1985) notes that Soviet Union has patented "propaganda state" during 1917-1929.

The first prominent theorists of propaganda are Harold D. Lasswell (1927, 1935), E. L .Bernays \& M. C. Miller (1928), F. E. Lumley (1933) and L. W. Doob (1935). Known for communication model launched in 1948, Harold D. Lasswell is the most important theoretician and practitioner of propaganda advisor of the twentieth century (During World War II, he was Chief of the Experimental Division for the Study of War Time Communications at the Library of Congress.) His works as sole author ["The Theory of Political Propaganda" (1927), "Propaganda Technique in the World War" (1938)] or in accomplice ["Propaganda, communication, and public Opinion: a comprehensive guide" (1946), "Propaganda and 
promotional activities. An Annotated Bibliography "(1969)] is established as a corpus for propaganda fundamentals. Outstanding works about propaganda writing T. H. Qualter (1962), J. Ellul (1962; 1965), J. A. C. Brown (1963), J.-M. Domenach (1965, 2004), A. L. George (1973), J. M. MacKenzie (1984), P. M. Taylor (1992; 1999), W. L. Hixon (1997), Noam Chomsky (2002), D. Miller (2004), N. Davies (2011), G. S. Jowett \& V. Donnell (2014).

\section{PYRAMID OF PROPAGANDA AND PHASES OF PROPAGANDISTIC PROCESS}

The propagandistic approach is always an act "premeditated" by a pronagator. propagandistic operator operates deliberates, relying on direct and indirect opagandis effects, meaning perceived as intentional, respectively as involuntary (Rovca, - 2; Roşc 2006; Borowski, 2014). They engage widely diverse communicational $\mathrm{m}$ cans and c bilit es into the project of propaganda and do not exclude the achievement some vels ch as instigation and agitation. In any case, these are used only $\mathrm{s}_{\mathrm{P}} /$ situat ns. The propagandistic activity may have various forms: propaganda a ion, ope nn or campaign. The propagandistic production involves financial and intellect a corts of a cer magnitude than those allocated in influence itself and intoxication. S ghei kotin (Ceakotin, 2004) believes that the propagandistic process is scientificall vas d on the $10 v i a n$ theory of the conditioned reflex. The driving motor is suggestion Pavlov sets fortl the suggestion in the same field as sleep and hypnosis, assessing that an der given in the context of suggestion is of guaranteed efficiency. The propagandistic process uses there rore on suggestion and refers to organising the production and circuit of the masses.

According to Chakotin, schematically,

- the base is the doctrine;

- doctrine is concentrate an.

- the program is synt 1 ved $i$ a

- the slogan is cen on.

S. Chakotin sh ws the more, aggestive it is, the more effective is the symbol and the better idea it send idea dion in the direction of the doctrine, the better it induces the emotional basi to which the con of propaganda guides, stirs, instigates, pushes: threat, compassion tred, terial interest etc. The pyramid of Chakotin shows that in order to propagate the ine, w need not rely on detailed expositions, argumentations (RovenţaFrumu 2000, de nonstrations (meaning, as we say, on conviction), but on implicit and sim te int mation, caning on symbols and slogans. The action of propaganda promotes a doc. $b$ a program on the way of symbols and slogans.

1 is turn, J. Ellul (1962) distinguishes two phases in the propagandistic process. The first phas $\%$ pre-propaganda or sub-propaganda is featured by coming into contact with the masses an knowing them. Here it would act what we call the principle of knowing and adapting to the target-audience. The second phase is an active propaganda, and the messages are triggered therein. Ellul (1962) states the following limits or preconditions of the efficiency of the propagandistic process: pre-existing attitudes, the propaganda being able to operate at first only therein, using them to gradually change them; global trends and sociological presuppositions of the society, propaganda not being able to reverse itself the fundamental course of the society's development; the need for consistency with the facts, the propaganda not being able to ever be just a display of ideas, but a presentation of ideas concerning the facts, 
and the propaganda in contradiction to facts can only succeed temporarily; the time limit (time, continuity and sustainability are required in propaganda); limit due to influences from abroad or from outside the group subjected to propaganda; unpredictability of people's direct reactions to propaganda (depending on the culture, their training, as well as on other individual and social factors).

According to Jean Cazeneuve (Cazeneuve, 1976, pp. 360-364), propaganda has two stages. The first stage is the ideological pre-propaganda. Therein, a picture is delimited, which includes: range of moment of stability values and social change, the echo of the facts of actuality and "dominant political myths" (economical progress, liberalism, soyemionty, national independence, socialism). By relating to this content found in the pre propas a stage, the propagandistic message is developed in the stage of propagar itself. I propagandistic text must provide the reader's holding by a title simultanerysly ressing topicality fact and claiming or ideology of the targeted subgroup. Further it must slio wa ds "the evidence of the final slogan".

The way from the title to the slogan must be transited "by ideas and sophisms or reasons which send to the undisputed evid nce of th te" lazeneuve, 1976, p. 363). What creates the propaganda itself (the title, to to sloga a the slogan) "is done, shows Cazeneuve (Cazeneuve, 1976, p. 363), in a rt of a tive sylogism in threesteps." The goal of developing the propaganda is to imp ou slogan wdence. "The slogan ensures the unit of propaganda" emphasises Car neuve (Cazeneu,e, 1976, p. 363). It ultimately faces through it the divergent and diversif tinterests of the subculture of the targetgroup. Extended effects are also provided though it: e group be hg "convinced by a different reading of the text" (Cazeneuve, 1976, p. 363).

\section{PRINCIPLES OF PROPAGANDA}

Having advertising and ideo ogv as sources and the lie and myth as basis (Moraru, 2009), propaganda is clea ao tIII wan-Marie Domenach, as aspiring to become a science through certain les and te iques. The main contribution of the renowned French specialist to theorisin the paganda onsists in preparing such rules. He is aware that nobody can pretend to ha accee to circumscribe propaganda to a number of functional laws. Propaganda is olymorphic an as almost infinite resources (Domenach, 2004, p. 64). The main obstac stre heping the laws is the large number of factors that need to be taken into account, the fâ at the $r$ is and techniques depend on context.

Domo he delops six "rules and techniques" (Domenach, 2004, pp. 63-109). The first one 1 "the rul of simplification and unique enemy". The second one is "the rule of dist on thoricature". The third one: "rule of orchestring". The fourth rule is the rule of transte. The fittn one is the rule of unanimity and contagion. The sixth one is the rule of counterp ganda. The rules developed by Domenach have value of principles.

A good propaganda action, operation or campaign is based on acquiring and applying principles. Within the activity of propaganda, the following principles operate, and in between brackets, we mention the equivalence of the twelve principles we developed with Domenach's six rules:

\section{A) Principles of the target-group:}

a) the first principle, that of knowing and adapting to the target-audience; 
b) the second principle, that of selecting a unique, uniform, homogenous public, or under homogenisation;

c) the third principle, that of applying the contagion (the principle Le Bon), Domenach's fifth rule. According to this principle, the reality that mental contagion always intervenes must be exploited, according to Gustave Le Bon (Le Bon, 1990), in order to determine the special characters of the masses and their orientation; within a mass of people, any feeling, any act is contagious, so contagious that the individual sacrifices easier their personal interest in favour for the collective one. This shows that the group puts pressure on the individual opinion; the various forms of conformism that arise in society are managed therein. According to Domenach, the idea of contagion belongs to F. Expinas. Expinas starts from lindints "wroth" behaviour of the sentinel-bee. This behaviour triggers the wrath of the tire hive; calls the mechanism underlying the phenomenon "law of contagion". Furttror, L on and Expinas reach the idea of contagion. Similar to bees, the individual whor is part on gro ap is much more sensitive to the reactions of the other individuals. Propag ta trig $r s$ the isent by the human example, by the brightness of the apostolate, by the es. the he, by the conviction of proselytism. The most common means of contagic are the den onstration, the rally and the parade. The crowd begins "to hit" in a unig a thm, by u g means such as: flags, banners, canopies, emblems, badges, inscription evice viforms, specific music, spotlights, torches, convergence gymnastics (Vlăduţes $a$, 2u96).

The unanimity is also a means of propag nda and demons ration of force. The individual in group is hardly permeable to propagan. The coms act groups are not sensitive to psychological contagion. The isolated individual he perfect element for the effect of the propaganda. Contagion then starts from tham. From a point of view, the soldier, the military, the militant, the member of a par member of a well structured group, such individuals are difficult to attract to an opinio $\mathrm{Th}$ ance of such an individual once it has been defeated, they can become the trigger of te contagion.

\section{B) Principles of the messag}

a) the fourth princ ple, that simplicity of the message (the ideational of the message must be simple) - firs of Dome 1 ; whatever the field where it would be manifested, propaganda shall pri arily ve to sinplify, direct everything in a few ideas which would be as clearly defin a as possib In this respect, in order to influence the audience, the propagandist 1 as ava 'able manl ests, professions of faith, programs, declarations, catechisms. These shalk eve oped an affirmative, concise, clear form and shall be directed towards one enemv;

tar aud hee, the ropagandistic message must be original and at the surface in agreement with lating on the projected direction). Propaganda is not done by starting from nothing. lways operates on an already existing sub-layer. The base of the transfer is the idea that the pry agandist must never contradict their audience. Anyway, they shall consent to the predominant emotion of the crowed since the beginning. The program must be connected to he audience's primary attitude;

c) the sixth principle, that of mono-thematics (when the projected message is formed from a set of messages, they must focus on a single topic);

c) the seventh principle, that of the rhetoric of repetition (Domenach's third rule): the message shall be developed having repetition as figure of speech. Gustave Le Bon shows (Le Bon, pp. 60-62) that there are three procedures to inoculate certain ideas and beliefs in the minds of the masses: affirmation, repetition and contagion; when an affirmation is repeated 
enough, it is unanimously formed what is called a trend of opinion, where the powerful mechanism of contagion intervenes; the contagion of emotions explains the rapidity by which the panic sets; the first rhetorical condition of a good propaganda is the uninterrupted repetition of main topics; the permanence of the topic is synthesised in watchwords and slogans; the topic must persist in various forms (Ştefănel \& Rovenţa-Frumuşani, 2010). As if confirming our principle of repetition rhetoric, Professor Mielu Zlate shows that: "the repetition of some formulations comes to lead to accepting the idea contained therein, independently of any verification (Zlate, 2004, p. 493);

e) the eighth principle, that of thematic recovery of myths (the topics of propasondistic messages shall be argumentatively anchored in the mythology well-known to the audio , this principle is also called the principle of transfusion, on the idea that those as needed support the topic of the propaganda are grafted on a pre-existing ideal-mytbical g nd;

f) the ninth principle, that of distortion (Domenach's second ruce): the dis tion of information is perceived by the masses as a novelty, and novelty is s as tr inforn cion; Gustave Le Bon (Le Bon, 1990) shows that the delivery of som les ce circul ing very rapidly at the level of crowds is not only the result of total creduly, but also oros distortions which the events become in the imagination of individuals $g$ at $d$ togethe ce most banal story becomes increasingly deformed, because the masses ink ictures, and the evoked image evokes in its turn other images in full logical ince mon ney in ro in to the first image; the distortion of news is a journalistic process (con monly used in negative journalism), by means of which the journalist highlights only the if ormation th thits them: a politician's hazardous phrase, announcement of an aircraft or un won ship s converted into threatening evidence; the skilful use of quotations detached from text is also a frequently used procedure.

\section{C) Planner's principles:}

a) the tenth principle, th t of o ganisatio Jased on a plan: any propagandistic action, operation or campaign must we iat on a

b) the eleventh priciple, $\mathrm{u}$ of feed (feed-forward + feed-back): the action must be allowed to flow as lon the desire cects and reactions are produced; one must intervene with corrections wh ever desired dffects and reactions are not achieved.

c) the ty princi that of counterpropaganda (Domenach's sixth rule). The propaganda y ich of mbats the opponent's theses focuses on a few directions: locating the topics of the on it s p paganda, attacking the weaknesses, abstaining from assailing the adverse propaga when $l$ is weak, debile, disdaining the opponent whom is under assault, puttin 5 oppon 'o propaganda in contradiction with the facts and ridiculing them, im sing 1 , own clii ate of force (Popa, 2006).

Domenach, propaganda has two sources: advertising and political ideology. Advert and propaganda shook hands a long time ago. Their evolution is parallel. At first, the doctrin are praised as the producer praises their products, meaning their features are described and benefits explained. As Domenach shows (Domenach, 2004, p. 29), "the programs and presentations of doctrines correspond to the informative advertising, which marks the beginning of the art of advertising".

The common procedures are manifold: "the profession of faith" corresponds to the ad, symbol corresponds to the brand, the political slogan corresponds to the commercial slogan. On the other hand, propagandas are inspired by the inventions and successes of publicity and copy a style which is deemed to be the audience's will. Over time, the slogan, repetition, attractive images increasingly gain more ground, to the detriment of serious and demonstrative 
announcements: it is concluded (Domenach, 2004, p. 30) that "from informative, publicity becomes suggestive". It is relied more and more on obsession and sexual instinct, procedures also acquired by political propaganda. Simultaneously, political propaganda tends to become a science. Its results are tested and they want their efficiency (Branea, 2009; Gheorghe, 2010). The suggestibility of modern man is also exploited: they hardly abscond from an obsession, a certain procedure of attracting. Now, the product is no longer imposed to the customer, but the need for the product is induced to them. Advertising creates needs.

What modern technicians of propaganda have not discovered is that "the individual in the middles class is a being basically liable to influence" (Domenach, 2004, p. 20). It manns it is possible to induce beliefs which they shall consider to be theirs, it is possibl to litu change their ideas. Part of the propaganda survives even today in symbiosis $y$ advertisit "The propaganda of publicity type" is limited to election campaigns, a case wher tain ide are valorised.

If the sources of propaganda are publicity and ideology, its foun tions a acco ng to Domenach, the myth and the lie. The first propaganda within e "pro yganda", "propaganda fide" is Christian propaganda, and this first propa anda of ctian cy "owes a great deal to eschatological myth". The new political pre pa das are a rooted in a mythology of liberation and redemption. Domenach yce the cept of "myth" in the acceptation given by Sorel. People participate at the ocan ocial mo conts, they represent their action which they execute as images of fightin for their own cayse, an approach where they come out in triumph from (Coman, Radu, Pre easa, Păun, Bădău, 2011). The myth is such a mental construction. Concerning the lie, it 1 been ma e obvious by our era: false speeches and communiqués abound.

The psychological foundations of prop are polarised on the idea that "individuals like to dream" (Domenach, 2004, p. 123). O e c alingainst the lie and myth only with facts. The insidiousness of proparanda has so destroyed this pillar, which makes "the distinction between propagand a an inform ion become increasingly more difficult". Propaganda "has learnt to hid alf b hind apprently objective information".

\section{CONCLUSION}

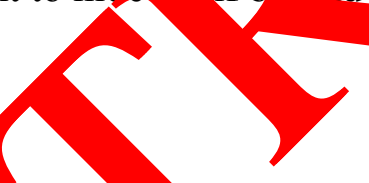

The strateg of propag ástic persuasion is developed by benefiting from the propagandis prest " by the seduction produced by the "scholarly" assertions, but which lack evidence, ie shoc of the myths drawn into natural reasoning, on repeating which act as sub for ation, on the permeability to seduction and suggestion, on mental

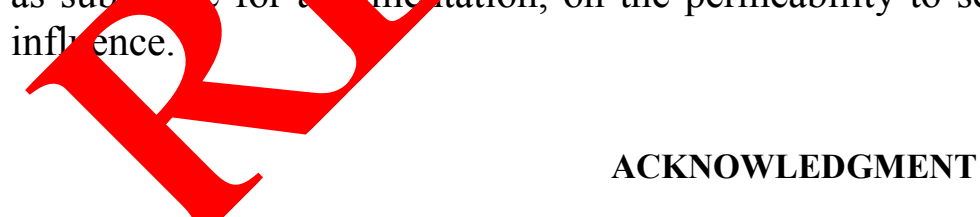

This work was partially supported by the grant number 33C/2014, awarded in the internal grant competition of the University of Craiova. 


\section{References}

[1] S. Ceakotin (2004). Violul mulţimilor prin propaganda politică. Bucureşti: Editura Antet.

[2] Andrzej Borowski, International Letters of Social and Humanistic Sciences 14 (2014) 7-17.

[3] Jason L. Powell, International Letters of Social and Humanistic Sciences 16(2) (2014) 177-183.

[4] Sebastian Kot, Janusz Grabara, Michal Kolcun, International Letters of Socj and Humanistic Sciences 15 (2014) 1-6.

[5] G. Le Bon (1990). Psihologia mulţimilor. Bucureşti: Editura Anima

[6] Mielu Zlate (2004). Psihologie organizaţional-managerială. Iaşi ritura lirøm.

[7] J. Ellul (1962). Propagandes. Paris: Armand Colin.

[8] J. Cazeneuve (1976). La Communication de Masse. Guid a abétique. Is: DenoëlGonthier.

[9] J.-M. Domenach (2004). Propaganda politică. Iar. Editura Institu European.

[10] R. Sampaio (2003). Propaganda de A a Z (Vo 4). Elsevier Brasil.

[11] Andrzej Borowski, International Letters of Soc nd Hun anistic Sciences 14 (2014) $33-41$.

[12] G. S. Jowett, V. O'Donnell (2014). Prop yar yersuasion. Sage.

[13] J. D. Squires (1935). British Paganda t Home and in the United States from 1914 to 1917, (Vol. 6). Cambridge arvà Univer ty Press 1935.

[14] H. C. Peterson (1968) aro The campaign against American neutrality, 1914-19 1. Kennt. Press.

[15] J. A. Leith (196 0. D. dea of ary as propaganda in France, 1750-1799: a study in the history of id Vol. $\delta$, Iniversity of Toronto Press.

[16] M. Balfo ar (19 9). Propag anda in War, 1939-1945: Organisations, Policies, and Publics, Brian an Germany (pp. 399-399). London: Routledge \& Kegan Paul.

[17] P The birth of the propaganda state: Soviet methods of mass mob zation, 1-1929. Cambridge University Press.

[18] swell, American Political Science Review 21(03) (1927) 627-631.

[19] Jan Grabara, Vladimir Modrak, Ioan Constantin Dima, International Letters of Socia and Humanistic Sciences 15 (2014) 148-156.

[20] E. L. Bernays, M. C. Miller (1928). Propaganda. Ig Publishing.

[21] F. E. Lumley (1933). The propaganda menace. doi.apa.org

[22] L. W. Doob (1935). Propaganda. Its psychology and technique. psycnet.apa.org

[23] H. D. Lasswell (1938). Propaganda technique in the world war. agris.fao.org 
[24] B. L. Smith, H. D. Lasswell, R. D. Casey (1946). Propaganda, communication, and public opinion: a comprehensive reference guide.

[25] P. Bajdor, I. Grabara, Journal of Studies in Social Sciences 7(2) (2014).

[26] H. D. Lasswell, R. D. Casey, B. L. Smith (1969). Propaganda and promotional activities: An annotated bibliography. University of Chicago Press.

[27] H. D. Lasswell (1995). Propaganda. Propaganda (Main Trends of the Modern World). Houndmills, Basingstoke: Macmillans.

[28] J.-M. Domenach (2004). Propaganda politică. Iaşi: Editura Institutul Europe

[29] T. H. Qualter (1962). Propaganda and psychological warfare (Vol. 41) dom House.

[30] J. A. C. Brown (1963). Techniques of persuasion: From propaga da to brainwashing (Vol. 604). Middlesex, England: Penguin books

[31] M. Coman, R. Radu, M. Preoteasa, M. Păun, H. Bădău (20 1). Roma · Ty nty Years of Professionalization in Journalism-still Counting. ng

[32] J. Ellul (1965). Propaganda: The formation of men' 306. Kellen (Ed.). New York: Knopf.

[33] J. M. Domenach (1965). La propagande politi e (Vol. 448 Presses universitaires de France.

[34] A. L. George (1973). Propaganda and is: A stuay, Jerences made from Nazi propaganda in World War II (pp. 109- 1)._ - Connecticut: Greenwood Press.

[35] A. Traistaru, M. Avram, International L te sof cial and Humanistic Sciences 13 (2014) 79-88.

[36] Andrzej Borowski, Inter ional Letters of social and Humanistic Sciences 4 (2013) 70-74.

[37] A. R. E. Rhodes 7). Propas da: the art of persuasion, World War II. Book Sales.

[38] P. M. Taylor ( 92). and the media: Propaganda and persuasion in the Gulf War. Mancheste Oriversity $\mathrm{F}$

[39] P. M. Mritish Propaganda in the Twentieth Century (pp. 27-29). Edinburg dinburg University Press.

[40] a.s. änel, b Rovenţa-Frumuşani, Journal of Journalism and Communication $2(20$ (2) $13-1$

[41] Tark (1997). Art and propaganda in the twentieth century: The political image in the age mass culture. New York, NY: Harry N. Abrams.

[42] A. R.Pratkanis, A. Pratkanis, E. Aronson (2001). Age of propaganda: The everyday use and abuse of persuasion. Macmillan.

[43] Luminiţa Roşca (2006). Mecanisme ale propagandei in discursul de informare: presa românească în perioada 1985-1995. Polirom.

[44] Luminiţa Roşca (2002). Forme de manifestare a propagandei în discursul totalitar. Jurnalism \& Comunicare. 
[45] Miller D. (2004). Tell me lies: Propaganda and media distortion in the attack on Iraq. Pluto Press.

[46] Mariana Popa (2006). Comunicarea-aspecte generale şi particulare. Editura Paideia, Bucureşti.

[47] Noam Chomsky (2002). Media control: The spectacular achievements of propaganda (Vol. 7). Seven Stories Press.

[48] Daniela Rovenţa-Frumuşani (2000). Argumentarea. Modele şi strategii. Bucureşti: BIC ALL.

[49] N. Davies (2011). Flat Earth news: an award-winning reporter exposes fo rehood, distortion and propaganda in the global media. Random House.

[50] W. L. Hixson (1997). Parting the curtain: Propaganda, culture, New York: St. Martin's Press.

[51] J. M. MacKenzie (1984). Propaganda and Empire: the mar puntio, Britis public opinion, 1880-1960. Manchester: Manchester University ss.

[52] Ştefan Vlăduţescu (2006). Comunicare jurnalistică nes tivă. curești:Editura Academiei.

[53] Silvia Branea (2009). The Romanian journalis between constralnts and liberties. Estudos.

[54] Mirela Gheorghe (2010). Elemente de retorică a Danubius. Communicatio.

[55] Jason L. Powell, International Letters of So lat ay Aumanistic Sciences 17(1) (2014) $1-60$.

[56] Mohsen Mehrara, Hamid brish ni, Most a Boroujli, Mahan Amin, International Letters of Social and 76-83.

[57] Andrzej Borowsk ternation. 100-105.

[58] Sele Sylves Eoisin, In national Letters of Social and Humanistic Sciences 2 (2014) $1-9$.

[59] Pawa To nterno jonal Letters of Social and Humanistic Sciences 3 (2014) 26-36.

[60] Jamo da. Aternational Letters of Social and Humanistic Sciences 3 (2014) 45-5

[61] ami, Hussein Meihami, International Letters of Social and Humanistic Sc. es 3 (2014) 80-91.

[62] Onyil.e Maggaret Odu, International Letters of Social and Humanistic Sciences 4 (2014) 31-39.

[63] Rajesh K. Yadav, Nishant Dabhade, International Letters of Social and Humanistic Sciences 4 (2013) 49-69.

[64] Uloma Charity Oguzor, International Letters of Social and Humanistic Sciences 4 (2014) 97-104. 
[65] Okezie A. Ihugba, Alex Odii, A. C. Njoku, International Letters of Social and Humanistic Sciences 5 (2014) 21-34.

[66] Okezie A. Ihugba, Bankoli Bankong, N. C. Ebomuche, International Letters of Social and Humanistic Sciences 5 (2014) 92-113.

[67] Tomáš Hes, Alena Neradová, Karel Srnec, International Letters of Social and Humanistic Sciences 7 (2013) 55-75.

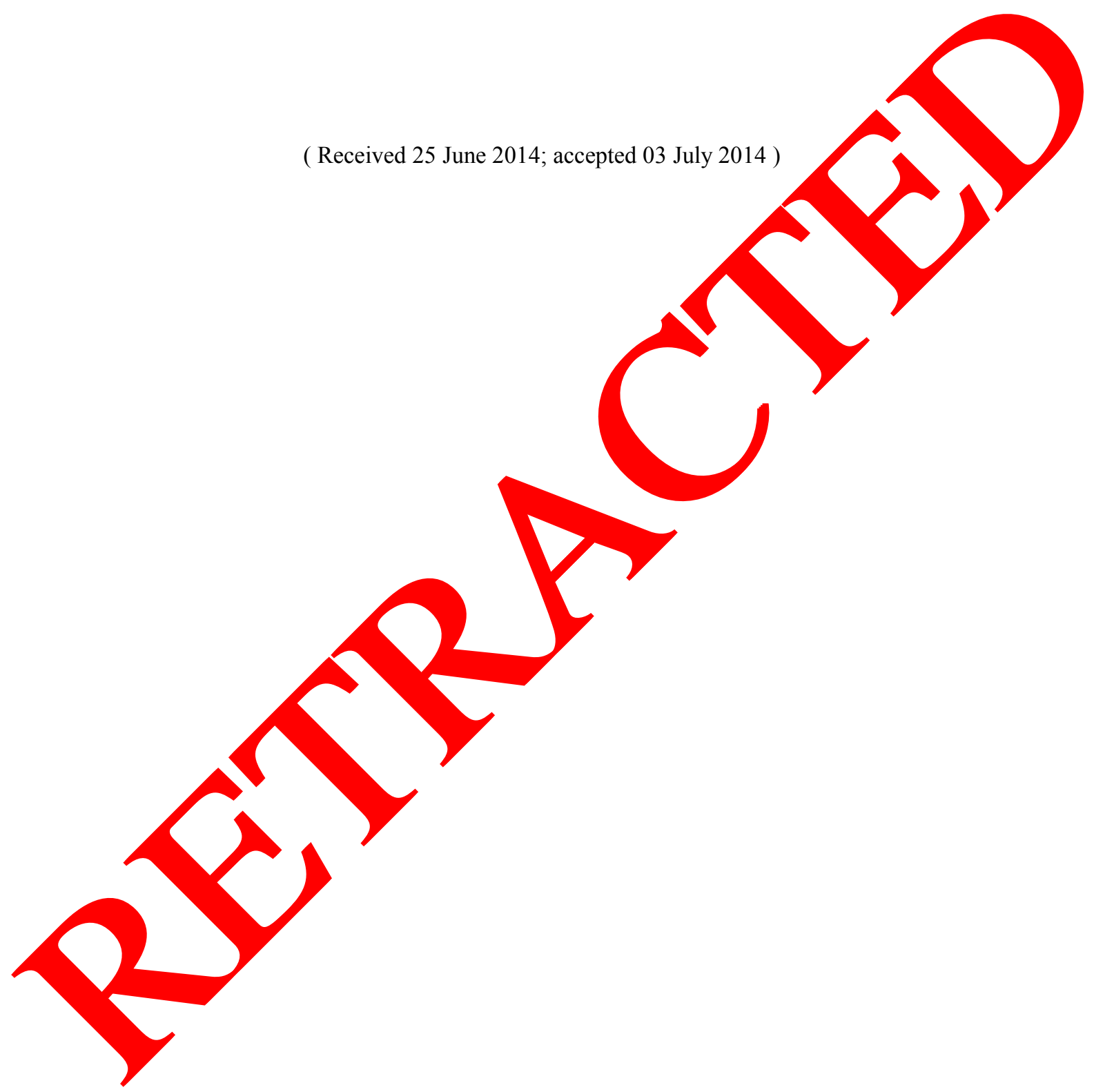

